\title{
Diagnosis of Pierce's Disease Using Biomarkers Specific to Xylella fastidiosa rRNA and Vitis vinifera Gene Expression
}

\author{
H.-K. Choi, F. Goes da Silva, H.-J. Lim, A. Iandolino, Y.-S. Seo, S.-W. Lee, and D. R. Cook
}

First and sixth authors: Department of Genetic Engineering, Dong-A University, Busan 604-714, Republic of Korea; first, fifth, and seventh authors: Department of Plant Pathology, University of California, Davis 95616; second author: Bio-Rad Inc., Hercules, CA 94547; third author: Department of Medical Laser, Dankook University, Cheonan 330-714, Republic of Korea; and fourth author: Monsanto Inc., Davis, CA 95616.

Accepted for publication 10 June 2010.

\begin{abstract}
Choi, H.-K., Goes da Silva, F., Lim, H.-J., Iandolino, A., Seo, Y.-S., Lee, S.-W., and Cook, D. R. 2010. Diagnosis of Pierce's disease using biomarkers specific to Xylella fastidiosa rRNA and Vitis vinifera gene expression. Phytopathology 100:1089-1099.

Pierce's disease (PD), caused by Xylella fastidiosa, represents one of the most damaging diseases of cultivated grape. Management of PD in the vineyard often relies on the removal of infected individuals, which otherwise serve as a source of inoculum for nearby healthy vines. Effective implementation of such control measures requires early diagnosis, which is complicated by the fact that infected vines often harbor high titers of the pathogen in advance of visual symptom develop-

Xylella-induced plant transcripts as well as Xylella ribosomal (r)RNA. Plant biomarker genes were derived from a combination of in silico analysis of grape expressed sequence tags and validation by means of reverse-transcriptase polymerase chain reaction (RT-PCR). Four genes upregulated upon PD infection were individually multiplexed with an $X$. fastidiosa marker rRNA and scored using either real-time RT-PCR or gelbased conventional RT-PCR techniques. The system was sufficiently sensitive to detect both host gene transcript and pathogen rRNA in asymptomatic infected plants. Moreover, these plant biomarker genes were not induced by water deficit, which is a component of PD development. Such biomarker genes could have utility for disease control by aiding early detection and as a screening tool in breeding programs.
\end{abstract} ment. Here, we report a biomarker system that simultaneously monitors
Pierce's disease (PD), caused by the xylem-dwelling bacterial pathogen Xylella fastidiosa, is one of the most threatening diseases to California's multibillion grape industry. The severity of outbreaks in the past two decades is attributed, in part, to the introduction of a highly mobile insect vector, the glassy-winged sharpshooter (Homalodisca vitripennis, formerly known as $H$. coagulata). As a consequence, considerable effort has been directed toward monitoring and controlling spread of the sharpshooter vector within the state of California. However, sustainable disease management will likely require the integration of vector control strategies, development and deployment of resistant grape cultivars, and intensive field management to remove infected individuals that otherwise serve as foci for secondary spread of disease.

The biology of PD involves changes to host water status, resembling drought stress. Moreover, it has been reported that extended drought conditions exacerbate the development of PD in vineyard-grown grapevines, because water-stressed grapevines appear more susceptible to PD than well-watered vines (15). Similarly, in controlled experiments using PD-infected Virginia creeper (Parthenocissus quinquefolia), a wild relative of cultivated grape, extended water deficit was correlated with accelerated symptom development $(23,24)$. X. fastidiosa is known to block the xylem vessels of infected plants, lending support to the longstanding hypothesis that many of the characteristic symptoms of PD (i.e., green islands, matchsticks, localized leaf scorch, and eventual death of vines) are caused by drought stress. By contrast, Thorne et al. (38) report that PD symptoms were not affected by any of several water-deficit treatments, including severing all but

Corresponding author: H.-K. Choi; E-mail address: hkchoi@dau.ac.kr

doi:10.1094/PHYTO-01-10-0014

(c) 2010 The American Phytopathological Society one secondary vein near the leaf tip. These authors suggest that factors other than water deficit are involved in the development of PD symptoms. Regardless of the mechanisms underlying disease development, our unpublished results reveal that a portion of the host's transcriptional response to Xylella spp. infection is similar to transcriptional responses to drought stress. Thus, it is important that plant biomarkers for PD detection be based on diseaseassociated transcripts that are not induced by water deficit.

In addition to the need to distinguish Xylella infection from drought stress, PD detection methods should also allow early and accurate disease detection in asymptomatic vines. Analytic methods that have developed to detect $X$. fastidiosa diseases include enzyme-linked immunosorbent assay (ELISA) $(16,29)$, dot immunobinding assay (DIBA), Western blotting $(7,14)$, immunofluorescence (26), and polymerase chain reaction (PCR)-based assays $(2,25)$. ELISA has long been a preferred diagnostic tool for late-season detection of PD, although the methodology is still not sensitive enough to detect the bacteria early in the developmental stage of PD. PCR-based assays have higher sensitivity and are currently more preferred for PD diagnosis $(9,30,35)$.

More recently, real-time quantitative PCR (qPCR) has emerged as an efficient diagnostic tool. Real-time PCR systems, such as TaqMan (Applied Biosystems, Foster City, CA), combine the high sensitivity of PCR with the high specificity of nucleic acid hybridization. In addition, the TaqMan system enables simultaneous detection of numerous molecular biomarkers using a multiplex PCR design (31). The first use of TaqMan chemistry for plant disease diagnosis was for the detection of potato viruses (36). Since then, the real-time PCR technique has been applied to detect a diversity of plant pathogens, including fungi $(6,40)$, bacteria $(34,39)$, and viruses $(10,28)$. For routine disease diagnosis, high-throughput automated analyses have been developed using 96- and 384-well platforms (27). Moreover, real-time PCR 
methods have been adopted for field-based disease diagnosis by developing portable real-time machines, such as the Miniature Analytical Thermal Cycling Instrument (4), Advanced Nucleic Acid Analyzer (3), SmartCycler (Cepheid, Sunnyvale, CA) and Ruggedized Advanced Pathogen Identification Devise (Idaho Technologies, Salt Lake City, UT). Among these portable realtime PCR systems, the SmartCycler has used for the detection of plant pathogens (35).

Sequencing and analysis of expressed sequence tags (ESTs) provided an early glimpse into the gene inventory of Vitis vinifera $(12,20)$. The majority of these EST data were obtained from nonnormalized cDNA libraries, allowing for in silico analysis of gene expression based on the distribution of EST frequency across libraries. Of importance to this study, several of these cDNA libraries were constructed from matched sets of $X$. fastidiosa-infected and healthy grapevines (12).

We hypothesize that a diagnosis system that is able to monitor the presence of pathogen ribosomal (r)RNA and of pathogeninduced host gene transcripts is potentially more robust than one focusing on a single factor, and could have utility for both field management and breeding. In this study, we used in silico analysis of EST data sets derived from healthy and $X$. fastidiosainfected grapevines to identify PD-induced transcripts. Following validation, four such genes were used to develop a multiplex PCR-based PD diagnostic system that enables simultaneous detection of both pathogen and host plant markers. Because water deficit has been implicated as a factor in PD symptom development, we also evaluated performance of this detection assay in healthy and infected plants exposed to various levels of controlled water deficit.

\section{MATERIALS AND METHODS}

In silico identification of plant marker genes. Among 58 cDNA libraries present in the grape genomics data sets (cgf.ucdavis.edu and compbio.dfci.harvard.edu/tgi/plant.html), 4 cDNA libraries were prepared using mRNA extracted from PDinfected grapevines (12). To identify candidate genes induced upon $X$. fastidiosa infection, we performed a Boolean search in a matrix containing nonredundant EST frequency across the $X$. fastidiosa-infected and X. fastidiosa-noninfected cDNA libraries. The EST data set was organized into unigene assignments (also called "tentative consensus sequences" [TCs]) that were derived from assemblies based on MegaBLAST and CAP3 $(12,19)$. TCs for which $>80 \%$ of ESTs originated from $X$. fastidiosa-infected cDNA libraries were selected for further characterization.

To confirm expression specificity in planta, three pairs of PCR primers were designed and tested for each gene (PrimerExpress software; Applied Biosystems), with the goal of producing PCR amplicons of $\approx 98$ to $102 \mathrm{bp}$. Products of conventional reversetranscriptase (RT)-PCR were analyzed at 25, 30, and 35 cycles to determine the optimum end point of PCR amplification for each gene.

Bacterial strain, culture condition, and inoculation. $X$. fastidiosa strain Fetzer was kindly provided by Bruce Kirkpatrick (University of California, Davis). The bacteria were grown at $28^{\circ} \mathrm{C}$ on PD3 agar medium for 2 weeks (8). For inoculation, bacterial cells were harvested and transferred into $2 \mathrm{ml}$ of sterile water and adjusted to an optical density at $600 \mathrm{~nm}$ of 0.25 $\left(10^{8}\right.$ cells $\left./ \mathrm{ml}\right)$. Bacterial suspension $(5 \mu \mathrm{l})$ was placed onto the base internode (the internode preceding the first leaf) of two grapevine canes and a 27-gauge hypodermic needle was pushed through the droplet and into the stem to allow uptake of the inoculum into the vascular system. Inoculation was conducted in triplicate on each base internode, with each inoculation site separated by an angle of $120^{\circ}$ around the stem.

Plant materials and stress treatments. Two-year-old vines $(V$. vinifera $\mathrm{L}$. cv. Cabernet sauvignon clone 8 grafted onto Richter110) were grown for one additional season under greenhouse conditions. At the end of the growing season, each plant was pruned so that two canes remained. After a 3-month dormancy period, the plants were transferred to growth chambers in a block design of three rows, with all treatments randomized in each row (temperature at $28^{\circ} \mathrm{C}$; photoperiod of $16 \mathrm{~h}$ of light and $8 \mathrm{~h}$ of darkness). Following 2 months of acclimation, the plants were pruned to yield a uniform canopy architecture consisting of two main shoots, each with 10 leaves, trained vertically in a "Y" configuration. Vines were watered daily with nutrient solution (of GrowMore 4-18-38, boron removed, at $0.11 \mathrm{~g} /$ liter) using a timercontrolled drop-irrigation system. Individual plants were exposed to one of three watering regimes. Maximum daily water usage was established by watering pots to field capacity and using a mini-lysimeter to quantify evapotranspiration. Throughout the remainder of the experiment, one-third of the plants were replenished daily with water at the calculated maximum rate, serving as the nonwater deficit treatment. Another one-third of the plants received water at $50 \%$ of the calculated maximum daily usage and the remaining one-third of the plants received water at $25 \%$ of the calculated maximum daily usage. Half of the plants from each watering-regime treatment were inoculated with $X$. fastidiosa as described above, with the other half serving as noninoculated healthy controls. All six treatment combinations of inoculation and water deficit were repeated on six separate plants, grown as two sets of three replicates in two different growth chambers. At 4 weeks after treatment (WAT), the third and fourth leaves were harvested from each plant and used for presymptomatic transcript analysis. At 8 weeks following the treatments, when symptoms were evident on infected individuals, the fifth and sixth leaves from the same grapevines were harvested for the post-symptomatic transcript analysis. Symptom development was recorded visually.

RNA isolation and cDNA synthesis. RNA was isolated using the protocol of Iandolino et al. (17), which we determined to be suitable for isolation of both bacterial rRNA and plant mRNA. To extract RNA, a 2-by-2-cm leaf section was sampled from each leaf in the region immediately above the petiole. Total RNA was used as template to synthesize first-strand cDNA using the Omniscript RT kit (Qiagen, Valencia, CA) according to the manufacturer's instructions. For purposes of multiplex PCR, the manufacturer's protocol was modified as follows. Before the reversetranscription reaction, total RNA was incubated at $65^{\circ} \mathrm{C}$ for 5 min. A $20-\mu 1$ reaction mixture was assembled to contain $1 \times$ RT buffer, $0.5 \mathrm{mM} \mathrm{dNTP}, 100 \mathrm{ng}$ of oligo dT primer (Invitrogen, Carlsbard, CA), $0.5 \mu \mathrm{M}$ Xf16S forward primer, 10 units of RNase inhibitor (Invitrogen), 4 units of Qiagen Omniscript RT, and $1.0 \mu \mathrm{g}$ of total RNA. The reaction mixture was incubated for $1 \mathrm{~h}$ at $37^{\circ} \mathrm{C}$ in a Tetrad thermocycler (MJ Research, CA).

PCR primers and probe design. PCR primers and probes were designed using Primer Express (version 1.5a; Applied Biosystems). Grapevine TCs identified by in silico analysis were used as template sequences for primer and probe design. Primer and probe sequences for $X$. fastidiosa $16 \mathrm{~S}$ rRNA (Xf16S) were those described by Schaad et al. (35) except that, here, we detected rRNA instead of rDNA. For multiplex real-time PCR, 5' fluorescent reporter dyes were used as follows: 6-carboxyfluorescein $(\mathrm{FAM})\left(\lambda_{\mathrm{em}}=518\right)$ for detection of grape transcripts and 6-carboxy-4,7,2',7'-tetrachloro-fluorescein (TET) $\left(\lambda_{\text {em }}=540\right)$ for detection of Xf16S rRNA. Black Hole Quencher (BHQ1) was coupled as the quencher dye. Both primers and probes were synthesized by Sigma-Genosys (The Woodlands, TX). Information on primer pairs and TaqMan probes is summarized in Table 1.

Conventional RT-PCR and real-time RT-PCR. Reaction conditions for both conventional and real-time RT-PCR were modified to optimize amplification. In particular, the reaction components of the TaqMan Core Reaction Kit (Applied Biosystems) were modified as follows. Twenty 5 - $\mu$ l real-time PCR reactions 
contained $1.0 \mu \mathrm{l}$ of cDNA template, $1 \times$ PCR reaction buffer, $2.5 \mathrm{mM} \mathrm{MgCl}_{2}, 0.25 \mathrm{mM}$ each dNTP, $0.5 \mu \mathrm{M}$ each primer, $0.5 \mu \mathrm{M}$ probe, and 1.5 units of HotStarTaq DNA polymerase (Qiagen). TaqMan probes were omitted for purposes of conventional RT-PCR. PCR thermocycling reactions were performed with a 15-min initial denaturation or activation step, followed by 40 cycles ( $\approx 30$ to 35 cycles for conventional RT-PCR) at $94^{\circ} \mathrm{C}$ for $20 \mathrm{~s}, 59^{\circ} \mathrm{C}$ for $20 \mathrm{~s}$, and $72^{\circ} \mathrm{C}$ for $20 \mathrm{~s}$, with a final extension step of $5 \mathrm{~min}$ at $72^{\circ} \mathrm{C}$ using the iCycler iQ Real-time Detection System (Bio-Rad Laboratories, Hercules, CA).

DNA standards were developed to calibrate quantitative PCR and for use in kinetic studies. Toward this end, grapevine or $X$. fastidiosa marker genes were PCR amplified, analyzed on $2 \%$ agarose gels, purified with the QIAquick PCR purification kit (Qiagen), and quantified using a spectrophotometer. Purified PCR products were used to prepare a standard dilution series so that individual reactions contained between $10^{1}$ and $10^{12}$ copies of each nucleic acid template.

Microscopy. Light microscopy was used to visually score tissue-level and gross cellular changes associated with the various pathogen and water-deficit treatments. Three petiole samples were analyzed for each treatment, prepared as follows. Petiole tissue was cut into $\approx 0.4-$ to $0.5-\mathrm{cm}$ segments and immediately immersed in FAA fixative $(50 \%$ ethanol, $5 \%$ acetic acid, and $3.7 \%$ formaldehyde) overnight, followed by dehydration through an ethanol series and, ultimately, paraffin embedding (Paraplast Plus; Fisher Healthcare, Houston). Then, 10- $\mu$ m sections of embedded tissue were obtained using a Microm HM 340E rotary microtome (Mirom, Waldorf, Germany). Sections were stained in $0.05 \%$ toluidine blue solution as described by Ruzin (33). Prepared slides were observed with a Leica DM5000B compound light microscope. Images were captured and scanned into digital format.

\section{RESULTS}

Identification of $X$. fastidiosa-induced biomarker genes. Using in silico analysis, we initially identified 20 genes with differential expression in $X$. fastidiosa-infected compared with healthy grapevines (Table 2). Annotation based on BLASTX (1) against GenBank's nonredundant protein database and Gene Ontology Consortium mappings (9) revealed several genes with unknown function, stress-related genes, and genes involved in general metabolism (Table 2). Of the 20 genes, 4 genes showed in vivo specific expression in $X$. fastidiosa-infected plants and consistent differential expression patterns for the three different PCR primer pairs tested (data not shown). These genes were chosen as potential biomarkers for further development of the PD diagnostic system.

Development of a multiplex PCR-based PD diagnostic system. Of three primer pairs used to test each plant marker gene, we selected one primer pair that showed the best performance in PCR amplification. The compatibility of primer pairs for each grape marker gene was tested in multiplex PCR reactions that included primers designed for amplification of $X$. fastidiosa rRNA (referred to subsequently as Xf16S). All four of the plant genes exhibited strong differential expression based on comparison of infected and healthy grape tissue; in fact, with the exception of the PSL, which possessed relatively high basal expression in healthy tissue, the plant biomarker genes yielded differential amplification typical of primers designed for detection of $X$. fastidiosa rRNA (Fig. 1A).

To facilitate simple analysis by conventional RT-PCR reactions, we designed the PCR primers to yield amplicons of differing size (i.e., $100 \mathrm{bp}$ for the grape biomarkers and $62 \mathrm{bp}$ for Xf16S), allowing reliable resolution of distinct reaction products upon electrophoresis through 2\% agarose gel (Fig. 1B). We also tested various combinations of Xf16S with each grape marker gene to identify the best dual-marker combination for multiplex PCRbased diagnosis. Of the four plant genes, AUXR (CTG1027596), when coupled with Xf16S, routinely yielded the best results in terms of quantitative balance and kinetic behavior during the competitive PCR amplification (see below).

For real-time detection in multiplex PCR reactions, reporter fluorophore molecules were selected to minimize overlap in their

TABLE 1. Primer and probe information for the selected biomarkers ${ }^{\mathrm{a}}$

\begin{tabular}{|c|c|c|c|c|c|c|}
\hline Name & Gene annotation & Gene ontology & $\begin{array}{l}\text { UCD contig } \\
\text { no. }\end{array}$ & $\begin{array}{l}\text { TIGR } \\
\text { TC no. }\end{array}$ & & Primer and probe sequence $\left(5^{\prime}-3^{\prime}\right)$ \\
\hline AUXR & Auxin-regulated protein & Unknown & CTG1027596 & TC38390 & $\begin{array}{l}\text { AUXR-F } \\
\text { AUXR-R } \\
\text { AUXR-P }\end{array}$ & $\begin{array}{l}\text { CAAGAGAATGTGCCCGCC } \\
\text { TGACCAACTGACTCCCATCTCC } \\
\text { FAM-ACAATTGTGCCGGAGAACCTTCCCC-BHQ1 }\end{array}$ \\
\hline TRT & Tropinone reductase & $\begin{array}{l}\text { Oxidoreductase } \\
\text { activity }\end{array}$ & CTG1027712 & TC38442 & $\begin{array}{l}\text { TRT-F } \\
\text { TRT-R } \\
\text { TRT-P }\end{array}$ & $\begin{array}{l}\text { TAAAGGCATCAGGAGCGGG } \\
\text { TCATTGCTCCTTTGGTCGC } \\
\text { FAM-TCTGTTGCAGGCGTAGTGTCACTCAAGTATCTG-BHQ1 }\end{array}$ \\
\hline PSL & Phloem-specific lectin & Unknown & CTG1030745 & TC39991 & $\begin{array}{l}\text { PSL-F } \\
\text { PSL-R } \\
\text { PSL-P }\end{array}$ & $\begin{array}{l}\text { TTGGTTGGCATTCAGCTCC } \\
\text { CATCATGTTTCTCTCTGTAGGACTCC } \\
\text { FAM-AGGTGAGACACAAAGGAGAAGAGACACACAG- } \\
\text { TAACATTAT-BHQ1 }\end{array}$ \\
\hline TAL & Tubulin $\alpha-6$ chain & Unknown & CTG1031276 & TC47243 & $\begin{array}{l}\text { TAL-F } \\
\text { TAL-R } \\
\text { TAL-P }\end{array}$ & $\begin{array}{l}\text { TTTCCGTCGGAATTCGAACTT } \\
\text { ACCCACCGGTCAAACACTGA } \\
\text { FAM-CCGGATTATAGTGCTTTGGCTGTCGGA-BHQ1 }\end{array}$ \\
\hline ATN & Actin & $\begin{array}{r}\text { Cytoskeleton } \\
\text { organization }\end{array}$ & CTG1027583 & TC45156 & $\begin{array}{l}\text { ATN-F } \\
\text { ATN-R } \\
\text { ATN-P }\end{array}$ & $\begin{array}{l}\text { AGCTGGAAACTGCAAAGAGCA } \\
\text { TTCTGGACAACGGAATCTCTCA } \\
\text { FAM-AACTATGAGCTGCCTGATGGGCAAGTCATTACT-BHQ1 }\end{array}$ \\
\hline
\end{tabular}

\footnotetext{
${ }^{a} \mathrm{~F}$, forward primer; R, reverse primer; $\mathrm{P}$, probe; N/A, not available; $5^{\prime}$ reporter dye, 6-carboxyfluorescein (FAM) or 6-carboxy-4,7,2',7'-tetrachloro-fluorescein
} (TET); 3' quencher dye, black hole quencher (Sigma Genosys Inc.). 
absorption and emission spectra. A combination of FAM for grapevine biomarkers and TET for Xf16S was chosen as the most suitable for the $5^{\prime}$ reporter molecules (Fig. 1B).

We assessed sensitivity and dynamic detection range of the diagnostic system under multiplex PCR conditions using various template concentrations ranging from 10 to up to $10^{12}$ copies (Fig. $2 \mathrm{~A}$ ). The calibration lines calculated by logarithmic regression were represented by the equations $y=-2.515 \times \mathrm{Ln}$ (number of copies) + 37.862, with $R^{2}=0.992$ for AUXR, and $y=-4.248 \times$ $\mathrm{Ln}+56.907$, with $R^{2}=0.995$ for Xf16S, respectively. High $R^{2}$ values were obtained for the standard curves with good reproducibility within each point of the serial DNA dilution, confirming the validity of the assay for quantification of the target PCR products (Fig. 2B). In multiplex PCR mixtures that contained the same copy numbers of both plant and bacterial marker genes, their amplification kinetics differed, with steeper slopes for Xf16S than AUXR, as reflected in their respective equations. (Fig. 2B). PCR efficiencies $(E)$ were calculated from the slopes of the standard curves according to the equation $E=10^{(-1 / \text { slope })}$ for serial dilution in steps of $10[\log (10)$ scale]. $E=2$ reflects a doubling of DNA in each PCR cycle. PCR efficiencies differed between the two biomarkers, 2.5 for AUXR and 1.8 for Xf16S. This difference is consistent with delayed amplification of the Xf16S marker gene compared with that of AUXR and is likely to derive from the combined effects of differing primer pair or probe sequences and different amplicon size. Despite these differences in amplification kinetics of the individual biomarker targets, the two biomarkers exhibited consistent and balanced kinetic behavior across a range of template concentrations during multiplex RTPCR (Fig. 2A).

TABLE 2. Xylella-induced genes identified by in silico analysis of grape expressed sequence tag (EST) database ${ }^{a}$

\begin{tabular}{|c|c|c|c|c|c|c|c|c|}
\hline \multirow[b]{2}{*}{ UCD contig ID } & \multirow[b]{2}{*}{ Gene description } & \multicolumn{2}{|c|}{ Top hit Blast $X^{b}$} & \multirow[b]{2}{*}{ Contig length (bp) } & \multicolumn{4}{|c|}{ EST frequency } \\
\hline & & GenBank ID & $E$ value & & Total & Infected $^{\mathrm{c}}$ & Healthy & Other tissues \\
\hline 1026969 & Hypothetical protein & N/A & $2.00 \mathrm{E}-47$ & 618 & 33 & 30 & 0 & 3 \\
\hline 1027596 & Auxin-regulated protein & NP850064 & $6.00 E-68$ & 593 & 121 & 121 & $\mathbf{0}$ & $\mathbf{0}$ \\
\hline 1027712 & Tropinone reductase & NP180489 & 3.31E-101 & 1,109 & 34 & 30 & 2 & 2 \\
\hline 1028140 & $29 \mathrm{kDa}$ ribonucleoprotein $\mathrm{A}$ & Q08935 & $3.12 \mathrm{E}-89$ & 1,237 & 11 & 9 & 0 & 2 \\
\hline 1028253 & Ultraviolet-B-repressible protein & AAQ21122 & $4.88 \mathrm{E}-13$ & 625 & 14 & 12 & 0 & 2 \\
\hline 1028622 & Hypothetical protein & N/A & N/A & 450 & 10 & 9 & 1 & 0 \\
\hline 1028703 & Unknown protein & AAG12204 & 8.03E-29 & 858 & 17 & 16 & 0 & 1 \\
\hline 1028928 & Auxin-induced protein family & NP182192 & $6.69 \mathrm{E}-31$ & 741 & 12 & 12 & 0 & 0 \\
\hline 1029857 & Hypothetical protein & CA816382 & $8.17 \mathrm{E}-31$ & 498 & 6 & 5 & 0 & 1 \\
\hline 1029891 & Hypothetical protein & NP200514 & $2.00 \mathrm{E}-115$ & 885 & 8 & 7 & 1 & 0 \\
\hline 1030236 & Hypothetical protein & NP201538 & $1.00 \mathrm{E}-151$ & 1,140 & 6 & 6 & 0 & 0 \\
\hline 1030274 & Hypothetical protein & NP199782 & $9.00 \mathrm{E}-102$ & 1,024 & 6 & 6 & 0 & 0 \\
\hline 1030530 & 50S ribosomal protein L9 & NP190075 & $4.10 \mathrm{E}-51$ & 972 & 7 & 7 & 0 & 0 \\
\hline 1030745 & Phloem-specific lectin & NP197844 & 4.28E-11 & 838 & 8 & 8 & $\mathbf{0}$ & $\mathbf{0}$ \\
\hline 1031056 & Ethylene-induced esterase & AAK58599 & $3.00 \mathrm{E}-63$ & 931 & 8 & 8 & 0 & 0 \\
\hline 1031276 & Tubulin $\alpha-6$ chain & AAM62712 & 6.51E-39 & 733 & 6 & 6 & $\mathbf{0}$ & $\mathbf{0}$ \\
\hline 1031330 & Hypothetical protein & NP196111 & $2.00 \mathrm{E}-76$ & 958 & 6 & 6 & 0 & 0 \\
\hline 1031534 & Hypothetical protein & BAB09965 & $6.00 \mathrm{E}-76$ & 651 & 7 & 7 & 0 & 0 \\
\hline 1032262 & Hypothetical protein & AAN62336 & $3.00 \mathrm{E}-122$ & 905 & 6 & 5 & 0 & 1 \\
\hline 1032400 & DNA-binding protein $\mathrm{p} 24$ & AAF91282 & $3.40 \mathrm{E}-72$ & 1,006 & 6 & 6 & 0 & 0 \\
\hline
\end{tabular}

${ }^{a}$ Upregulated genes verified by RT-PCR experiment are highlighted in bold.

${ }^{\mathrm{b}} \mathrm{N} / \mathrm{A}=$ not available.

${ }^{\mathrm{c}}$ Infected by Xylella fastidiosa.

A
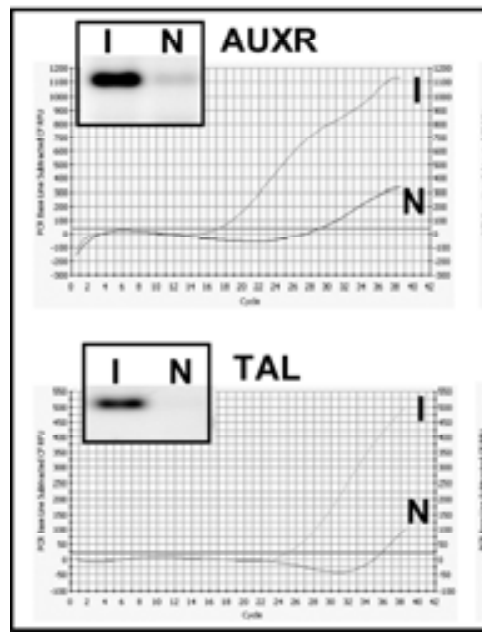
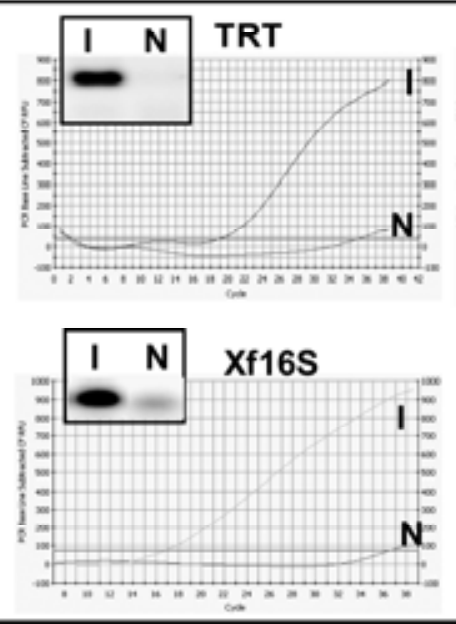
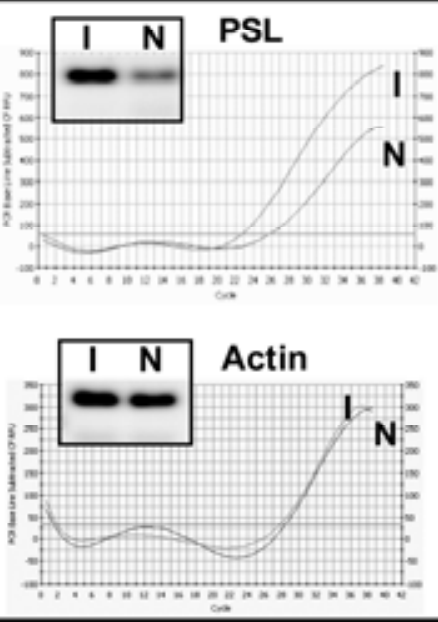

B

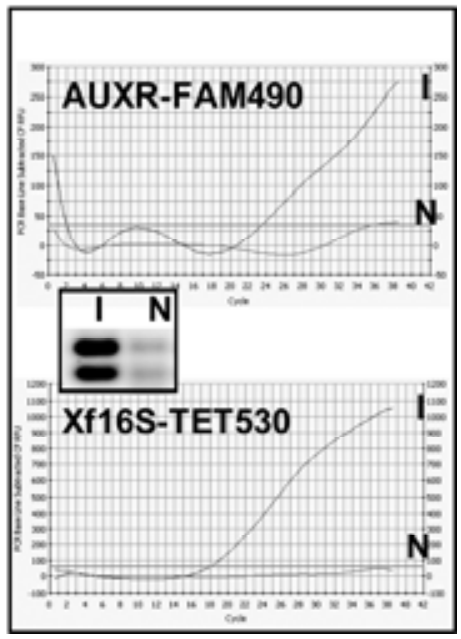

Fig. 1. Development of the Pierce's disease dual detection system. Comparisons of conventional reverse-transcriptase polymerase chain reaction (RT-PCR) with real-time RT-PCR of A, singleplex and B, multiplex PCR-based diagnostic system. Five plant genes, four Xylella-upregulated genes and actin gene as a positive control and one Xylella gene were tested for the singleplex as well as multiplex PCR analyses. AUXR, auxin-regulated protein; TRT, tropinone reductase; PSL, phloem-specific lectin; TAL, tubulin $\alpha$-6-chain; Xf16S, Xylella fastidiosa 16S ribosomal DNA; ATN, actin; N, noninoculated control; and I, X. fastidiosainoculated grapevine. Two 5' reporter fluorophore molecules were used for multiplex real-time PCR system: FAM490 for the AUXR grape gene and TET530 for the Xf16S Xylella gene. 
A

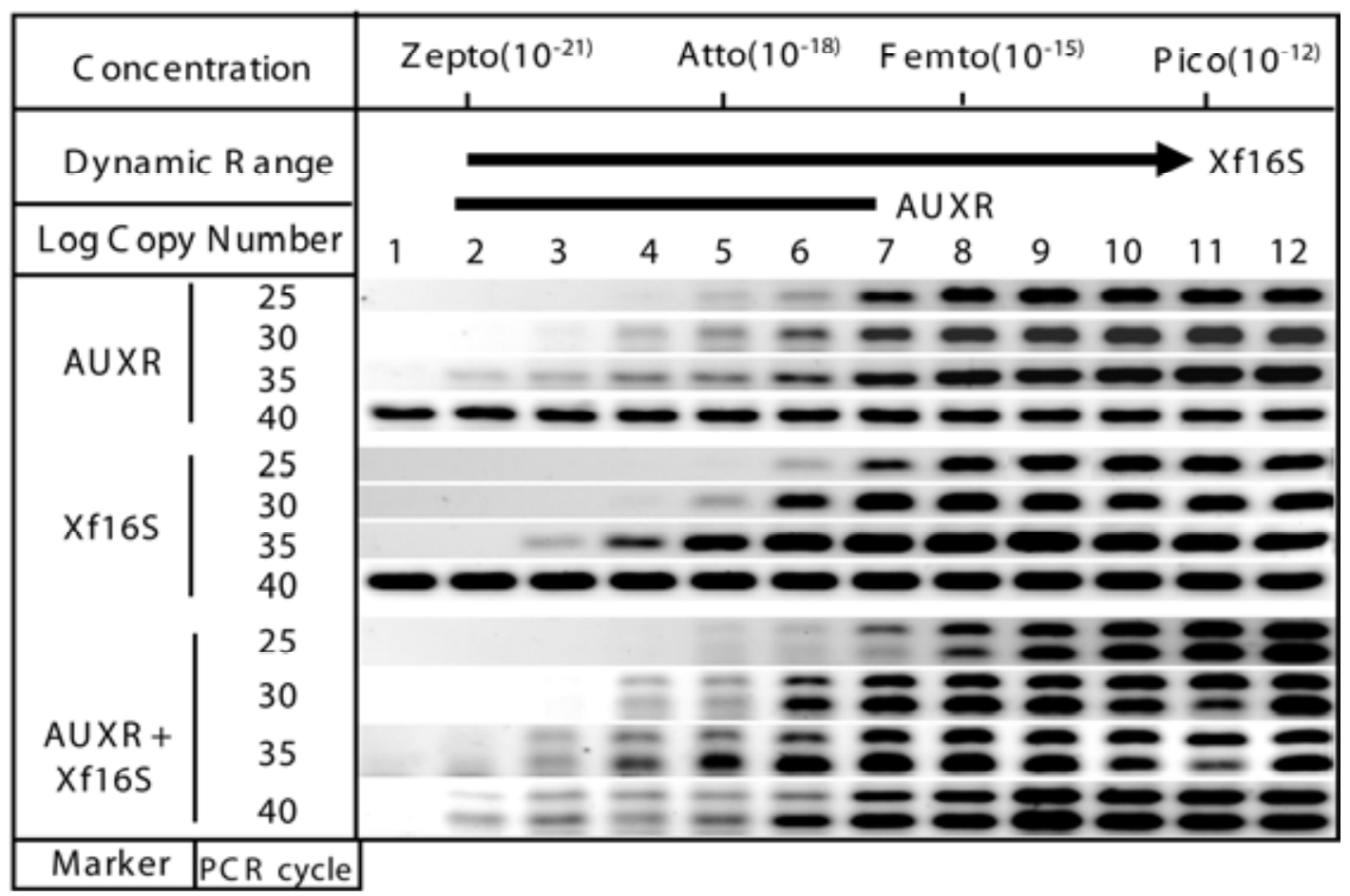

B

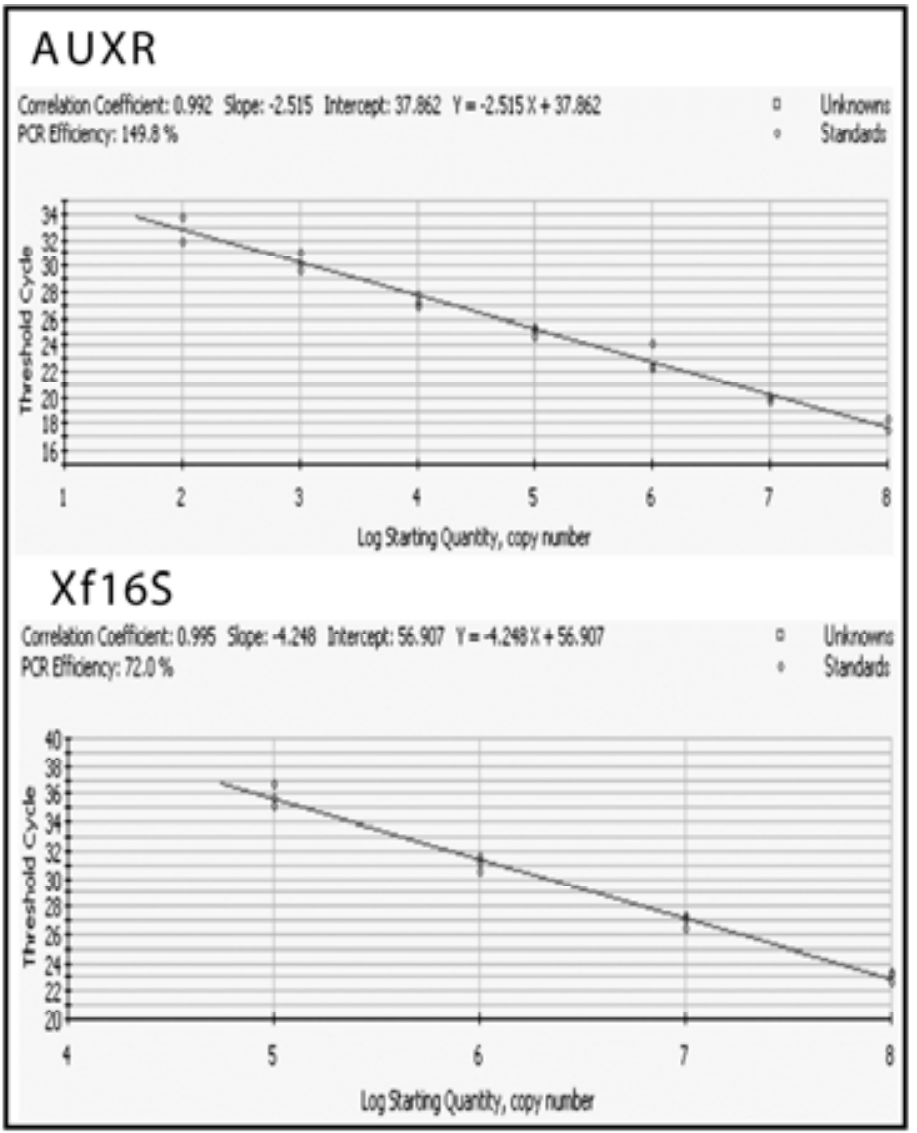

Fig. 2. Sensitivity, standard curves for quantification, and dynamic detection range of the diagnostic system. A, Sensitivity and dynamic detection range of the diagnostic method with conventional reverse-transcriptase polymerase chain reaction (RT-PCR) for AUXR, Xf16S, and AUXR+Xf16S. B, Sensitivity and quantitative standard curves of real-time PCR for AUXR and Xf16S, respectively. The standard line equations for logarithmic regression are $Y=$ $-2.515 \times \operatorname{Ln}$ (number of copies) +37.862 with $R^{2}=0.992$ for AUXR and $Y=-4.248 \times \operatorname{Ln}+56.907$ with $R^{2}=0.995$ for Xf16S. 
Symptom development in $X$. fastidiosa-inoculated and drought-stressed grapevines. PD symptoms on the experimental material 10 WAT are shown in Figure 3, revealing that growth chamber conditions were appropriate for symptomatically normal disease development. Marginal leaf scorching was first evident on some leaves 6 weeks after inoculation. By 10 weeks postinoculation, disease lesions were progressively larger and evident on some leaves of all inoculated plants (Table 3; Fig. 3). Berry mummification was evident on inoculated plants $\approx 2$ to 3 weeks after the leaf symptoms emerged, while other characteristic PD symptoms such as green islands (unevenness of periderm maturation) and matchsticks (petioles that remain attached to the stem after the laminae have fallen off) were never observed during the course of these experiments.

Both $X$. fastidiosa-inoculated and drought-stressed grapevines exhibited several common symptoms, including leaf chlorosis. Nevertheless, the patterns of leaf-symptom development were readily distinguished. In $X$. fastidiosa-inoculated grapevines, chlorosis or scorch (necrosis) were largely limited to leaf margins whereas, in drought-stressed grapevines, chlorotic symptoms were distributed across individual leaves and necrosis at the leaf margin was minimal. Grapevines treated with $X$. fastidiosa and water deficit showed a combination of symptoms caused by both stresses, and they were often more severe in appearance (Fig. 3E). Despite the development of foliar phenotypes, berries on droughtstressed plants were not mummified.

Examination of semi-thin paraffin sections of petiole tissue revealed decreased cell size in both drought-stressed and X. fastidiosa-infected grapevines (compare xylem cell size in comparably magnified images of Fig. 4B, E, H, and $\mathrm{K}$ with C, F, I, and L). A well-known consequence of drought stress is a reduction in the presence of starch granules. Consistent with this known relationship, starch granules were abundant in petiole sections of wellwatered control plants (Fig. 4C) but not detectable in petioles of water-deficit plants or in petioles of symptomatic leaves infected with $X$. fastidiosa. These simple observations extend the similarity between PD and water deficit and provide a contrast to the identification of disease-specific gene transcription, described below.
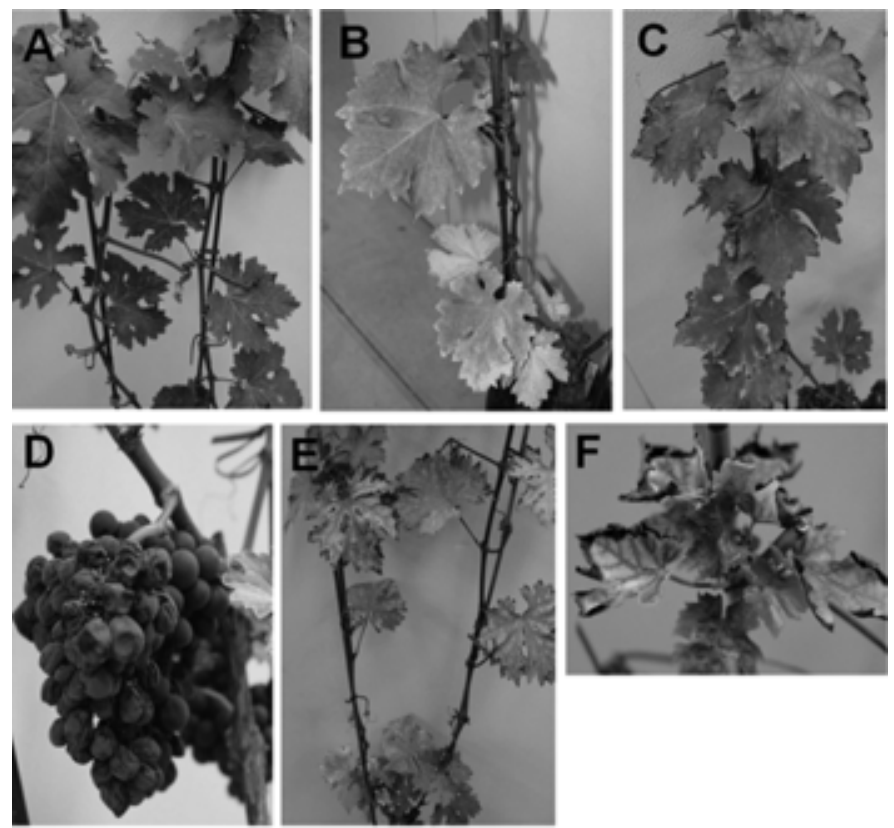

Fig. 3. Symptom development associated with Xylella fastidiosa infection and water deficit in grapevines. A, Nontreated control; $\mathbf{B}$, drought stressed; $\mathbf{C}, X$. fastidiosa inoculated; D, mummified berry in $X$. fastidiosa-inoculated grapevine; $\mathbf{E}$, double treatment of $X$. fastidiosa and drought stress; $\mathbf{F}$, marginal leaf scalding in emerging leaves of secondary shoots. Symptoms were monitored 4 to 10 weeks after the treatments.
Grapevine gene expression in response to $X$. fastidiosa infection and water deficit. To further examine the correlation between PD and drought stress, we conducted multiplex real-time RT-PCR and compared transcript levels of the four X. fastidiosainduced genes under conditions of increasing water deficit, pathogen infection, or a combination of water deficit and pathogen infection. Relative expression levels $(\Delta \mathrm{Ct})$ were estimated by subtracting average threshold cycles (Cts) of each gene $(\mathrm{Ct} \times$ $\mathrm{X}_{\mathrm{avg}}$ ) from the $\mathrm{Ct}$ of nontreated controls $\left(\mathrm{Ct} \times \mathrm{N}_{\mathrm{avg}}\right) . \Delta \mathrm{Ct}$ calculation showed that the water-deficit regimes (i.e., sustained application of either 50 or $25 \%$ of maximum water usage) imposed in this study did not greatly affect the expression of the grape marker genes (Fig. 5).

Although a high titer of $X$. fastidiosa was detected in the early stages of the disease progression (i.e., 4WAT), such plants remained symptomless. Expression of the PD biomarker genes was evident during this period, though relatively low compared with that observed in symptomatic plants at 8WAT (Fig. 5). AUXR and TRT revealed the most consistent induction at early time points, with $\Delta \mathrm{Ct}$ values indicating induction on the order of two- to eight-fold relative to healthy control plants. These results suggest that, in general, increased pathogen titer precedes host gene expression, while host gene induction precedes symptom development.

Evaluating multiplex RT-PCR in a highly replicated assay. To estimate the accuracy and reliability of plant biomarker genes for disease detection in infected grape tissue, we tested all five biomarkers (plant and bacterial) in a sixfold replicated set of grapevine samples grown under differing regimes of water deficit and $X$. fastidiosa inoculation (see Materials and Methods for a complete description of the biological material). All five biomarkers were tested in individual RT-PCR reactions in addition to two multiplex combinations involving AUXR/Xf16S and TRT/Xf16S. Separate reactions were performed for conventional gel-based and real-time fluorescent detection, with the difference being the absence of the probe oligonucleotide from the conventional reactions. All host biomarker genes were upregulated in $X$. fastidiosa-infected compared with healthy or drought-stressed tissues (Fig. 6A, rows 1 to 4 and 7); these results extend our earlier analysis and demonstrate reproducibility of the assay.

Because we had previously concluded that the AUXR/Xf16S multiplex was the most reliable, we focused primarily on this primer combination in the replicated multiplex assay. The TRT/Xf16S multiplex was conducted as a benchmark to reassess the presumed superiority of the AUXR/Xf16S biomarker pair. Comparison of the first and seventh row of Figure 6A, where the AUXR and Xf16S biomarkers were tested individually, with row 5, where AUXR and Xf16S were tested in multiplex, reveals highly consistent results within a sample between individual and multiplex amplification reactions. This result demonstrates both reproducibility of the assay and that amplification of neither AUXR nor Xf16S was impeded in the multiplex. Interestingly,

TABLE 3. Visual evaluation of Pierce's disease (PD) symptom development ${ }^{\mathrm{a}}$

\begin{tabular}{lccc}
\hline & & \multicolumn{2}{c}{ PD symptoms } \\
\cline { 3 - 4 } Treatment & No. of plants & Scorching $^{\mathrm{b}}$ & Mummification $^{\mathrm{c}}$ \\
\hline Noninoculated control & 6 & 0 & 0 \\
Mock-inoculated & 6 & 0 & 0 \\
Xylella fastidiosa-inoculated & 8 & 8 & $3(7)$ \\
Drought & 7 & $7^{\mathrm{d}}$ & 0 \\
Double treatment & 8 & 8 & $3(6)$ \\
\hline
\end{tabular}

a Visual symptoms were inspected 10 weeks after the treatments.

b Marginal leaf scorching.

c Berry mummification. Numbers in parenthesis indicate the numbers of plants with the symptom of berry mummification at 16 weeks after inoculation.

${ }^{\mathrm{d}}$ Grapevine treated with water deficit showed general leaf chlorosis rather than characteristic marginal leaf scorching of PD symptom. 
there were cases where AUXR was a more sensitive early marker than was Xf16S; this conclusion is evident if one compares signal intensity in rows 1,5 , and 7 within columns I.GC-2.E.2, I.GC2.E.3, ID.GC-1.E.2, and ID.GC-2.E.3. Thus, there is biological heterogeneity between plant samples with respect to bacterial titers and host biomarker induction, especially in asymptomatic plants. The observation that the biological situation can be complex and variable lends credence to the value of monitoring both host and bacterial marker genes, because such parallel monitoring should reduce the incidence of false-negative outcomes and provide corroboration in cases where one biomarker yields low amplification.

\section{DISCUSSION}

In silico identification of grape biomarkers induced by PD infection. The current method of choice for laboratory diagnosis of PD is ELISA but ELISA is less sensitive than PCR-based assays. On the other hand, currently available PCR-based PD diagnostics have focused primarily on detecting the presence of $X$. fastidiosa using a DNA-based assay system $(5,9,30,35)$. In this study, we sought to combine PCR-based detection of pathogen nucleic acids with the analysis of PD-specific plant transcripts in a multiplexed assay. We mined EST data sets to identify $X$. fastidiosa-induced genes in cultivated grape, $V$. vinifera. A set of four genes whose EST profiles revealed differential induction between healthy and diseased tissue were tested for efficacy as diagnostic biomarkers in conjunction with the previously described $X$. fastidiosa $16 \mathrm{~S}$ rRNA marker (39).

Initially, we identified 20 genes with EST distributions that were suggestive of $X$. fastidiosa-induced expression (Table 2). All 20 genes were tested via conventional RT-PCR (data not shown) but only the 4 genes described above were consistently associated with diseased and not healthy tissue. The majority of these 20 genes had low levels of expression support in the EST database compared with a larger number of additional genes in the same data set analyzed and validated by Goes da Silva et al. (12). Low rates of expression validation for transcripts supported by low EST frequencies has been previously reported (11); therefore, this result was expected. Nevertheless, in silico analysis provided a simple means to identify differentially expressed genes, and the utility of such in silico approaches should increase given the availability and use of more extensive and sensitive $V$. vinifera microarrays for transcriptional profiling analysis.

One goal of this study was to develop a multiplex PCR protocol for detection of PD. Multiplex PCR has several potential advantages over singleplex PCR. It allows simultaneous amplification of two or more DNA or cDNA targets in a single reaction with probes that reliably distinguish each target entity. Monitoring of multiple biomarkers adds robustness to the assay, especially in biological systems where rates of infection or host responses are heterogeneous. In principle, multiple biomarkers could be tested using separate singleplex assays, although multiplex assays reduce workload and require less sample, factors that are especially important if the number of samples is large or the quantity of sample material is limited.

A potential complication in multiplex PCR amplification is interference between competing amplification products in a single reaction, as we determined to be the case in the TRT/Xf16S multiplex. Importantly, we were able to identify one multiplex combination of AUXR/Xf16S in which the amplification of distinct biomarkers was essentially independent. Moreover, the two biomarkers were often complementary in asymptomatic plants, such that relatively low pathogen titers occasionally occurred in plants with elevated AUXR transcript and vice versa. This complementarity should reduce the rate of false-negative outcomes, while falsepositive assays could be corrected for by re-analysis of split samples collected and stored at the time of initial sample processing.

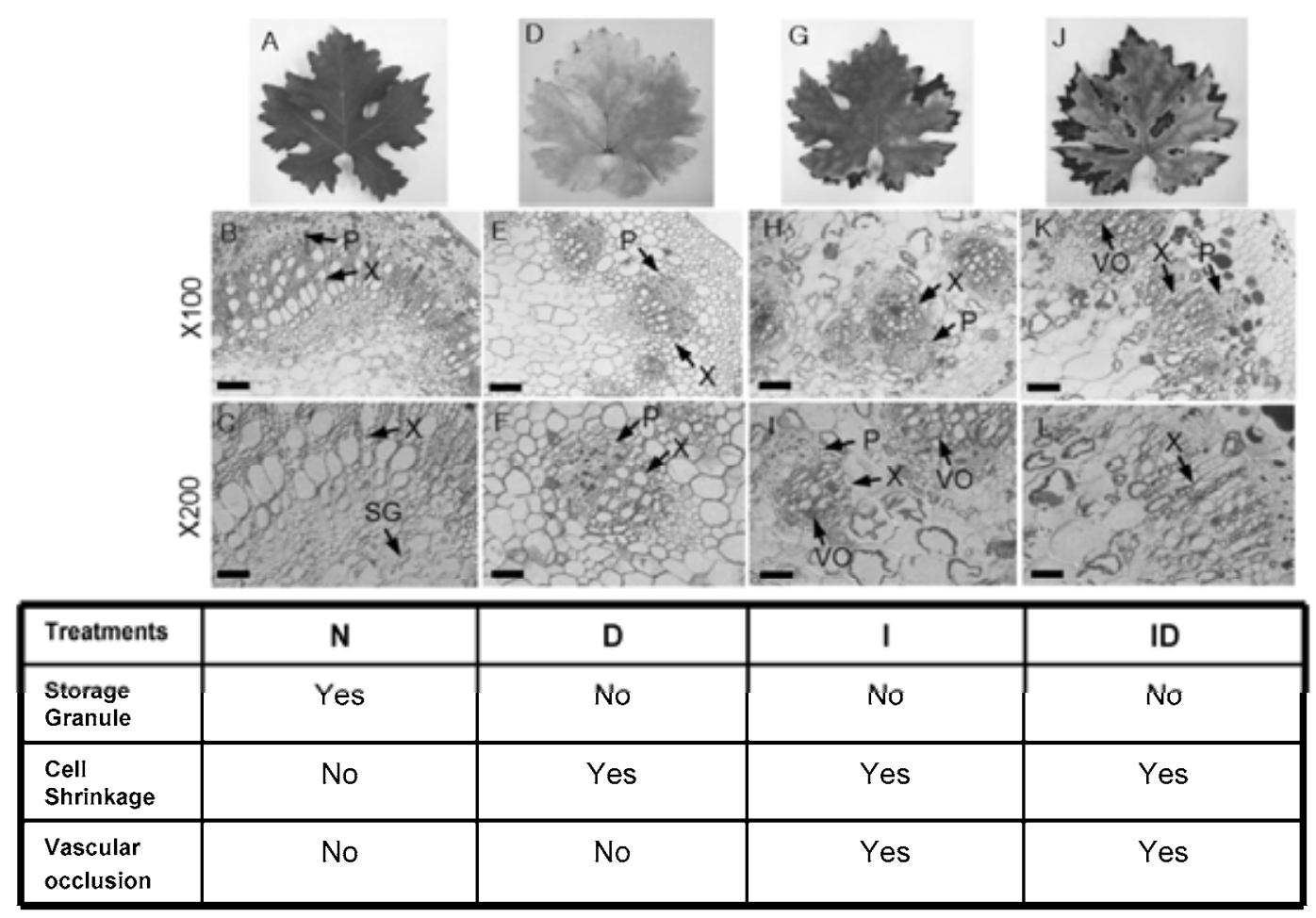

Fig. 4. Microscopic observation of grapevine petioles. The petiole tissues were sampled from symptomatic leaves 10 weeks after each treatment. A to C, Noninoculated control; D to F, drought-stressed; G to I, Xylella fastidiosa-inoculated; J to L, treated with X. fastidiosa-infection and drought. Abbreviations for the treatments are as follows: $\mathrm{N}$, noninoculated control; D, drought-stressed; I, $X$. fastidiosa-inoculated; ID, treated with $X$. fastidiosa infection and drought. Abbreviations for the tissues: X, xylem; P, phloem; VO, possible sites of vascular occlusion that are specific to infected petiole sections; SG, starch granule. Scale bars: $50 \mu \mathrm{m}$ for $\times 100$ samples and $25 \mu \mathrm{m}$ for $\times 200$ samples. 
Desired properties of disease-related biomarkers. Diagnosis of disease status is not a straightforward issue because many diseases are too complicated for a single analyte to serve as a trustworthy indicator of the disease status. In most cases, the

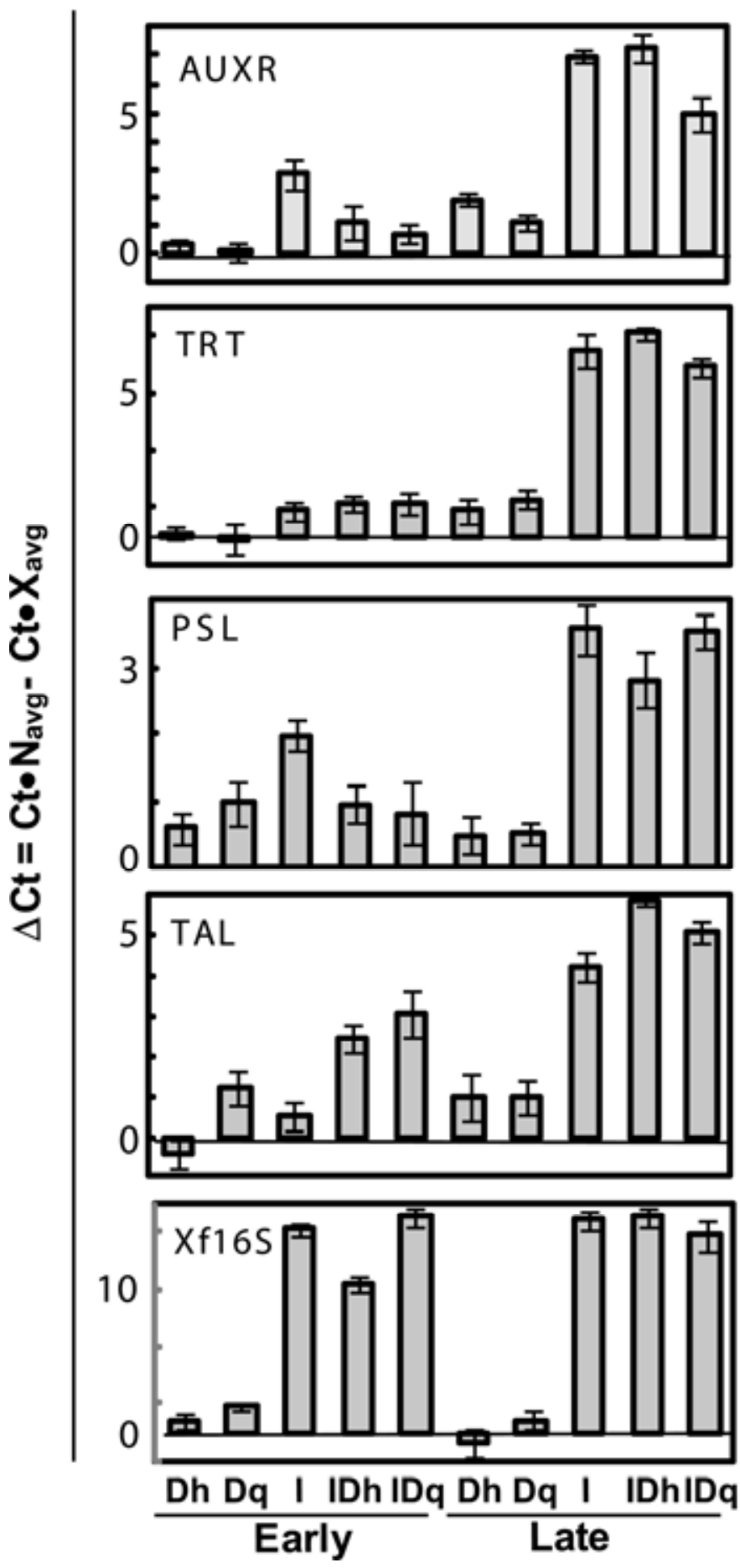

Fig. 5. Real-time polymerase chain reaction (PCR) expression analysis of Pierce's disease (PD)-induced genes. Leaf samples were taken 4 and 8 weeks after the treatment for the early- and late-stage expression analysis, respectively. Treatments: Dh, drought-stressed with half amount of daily water uptake; Dq, drought-stressed with quarter amount of daily water uptake; I, $X$. fastidiosa-inoculated; IDh, X. fastidiosa-inoculated and treated with half amount of daily water uptake; IDq, X. fastidiosa-inoculated and treated with quarter amount of daily water uptake. Real-time PCR was conducted with three replications for statistic data analysis. Gene expression level was estimated by calculating the mean difference of threshold cycles $(\Delta \mathrm{Ct}) . \Delta \mathrm{Ct}$ was calculated by subtracting average $\mathrm{Ct}$ of each gene from the average $\mathrm{Ct}$ of nontreated control. disease status is reflected by complex patterns of gene or protein expression from the interaction between host plant and pathogen $(22,37)$. Put simply, disease is a heterogeneously complex process. For example, many distinct technologies have been applied in human disease diagnostics, including gene expression, protein expression, SNP genotyping, and DNA methylation studies (22). However, even in human diagnostics, where a wealth of genomic and genetic information is often available, finding the appropriate biomarkers for use in a particular situation is often a difficult task. One strategy is to base the diagnostic assay on several correlated molecular targets, which, though more demanding in terms of upstream research, may be justified for the accurate diagnosis of economically important diseases.

In the case of PD of grape, vineyard-level management is recommended to include removal of infected vines, because infected vines can serve as sources of secondary disease spread. A complicating characteristic of PD is that asymptomatic plants with relatively high bacterial titers often exist in the field for months preceding the development of visual symptoms. Moreover, most diseased individuals contain a mixture of infected and noninfected sectors. Patchiness of infection complicates reliable sampling of asymptomatic plants, because the available diagnostic protocols require the presence of the bacterial pathogen in the analyzed sample.

We suggest that host biomarkers with the greatest potential to increase the fidelity of PD detection will be sufficiently sensitive to detect disease in asymptomatic tissue and induced systemically even in cases of patchy distribution of the pathogen. None of the four biomarker genes that we have tested here fulfill both of these criteria. The AUXR gene, which performed best in multiplex PCR reactions, performed as effectively as primers directed against $X$. fastidiosa rRNA (Fig. 6, replicated analyses); however, analysis of tissue distant to sites of infection failed to detect systemic induction. Similarly, none of the remaining three genes exhibited systemic expression in infected individuals. We conclude that these four genes are part of host response mechanisms that occur primarily at or near to sites of bacterial colonization. Therefore, additional work is required to identify systemically upregulated transcripts that are correlated with $X$. fastidiosa infection in grape. Toward this end, we have recently completed a genome-scale transcript profiling analysis of $\mathrm{PD}$-infected $V$. vinifera $(\mathrm{H} . \mathrm{-K}$. Choi, unpublished data) and the results are yielding a large number of candidate biomarkers that can be tested for early and systemic expression.

Correlation of PD with water deficit and as diagnostic specificity of markers. There has been a long-lasting disagreement about the mechanisms that underlie symptom development in $X$. fastidiosa-infected grapevines. It is well established that bacterial products, including cell aggregates and extracellular polysaccharides, along with host structures such as tyloses and gums, occlude grape xylem vessels and restrict water flow. Indeed, low leaf water potential and turgor, impaired hydraulic conductance, and higher stomatal resistance were correlated with PD symptoms in grapevines (13). However, whether vessel occlusion and the resulting water stress are a primary factor in symptom and disease development remains a topic of debate (e.g., see 17,23 , and 42 for differing conclusions). Other possible disease mechanisms include bacterial phytotoxins (18) and programmed cell death or a combination of these or unknown factors.

In this study, $X$. fastidiosa-inoculated and water-deficit-treated grapevines exhibited shared features of leaf chlorosis, alterations to vascular anatomy, and the absence of starch storage granules in petiole sections whereas other symptoms, such as marginal scorching and berry mummification, were specific to $X$. fastidiosa infection (Figs. 3 and 4). Regardless of the mechanistic relationship between water deficit and development of PD, it is clear that biomarkers for PD diagnosis should readily distinguish water- 
stressed plants from those infected by $X$. fastidiosa. Inclusion of bacterial markers in the assay is one resolution to this problem but plant biomarker genes whose expression is induced during disease have additional positive attributes, including complementarity with the bacterial assay and the intriguing possibility that some host biomarkers might be sensitive systemic indicators of in- fection. As described above, none of the four genes tested in this work exhibit the desirable property of systemic upregulation upon $X$. fastidiosa infection.

The results presented here are inconsistent with a simple "drought-stress only" hypothesis, because they indicate the existence of a transcriptional response pathway that is characteristic

A

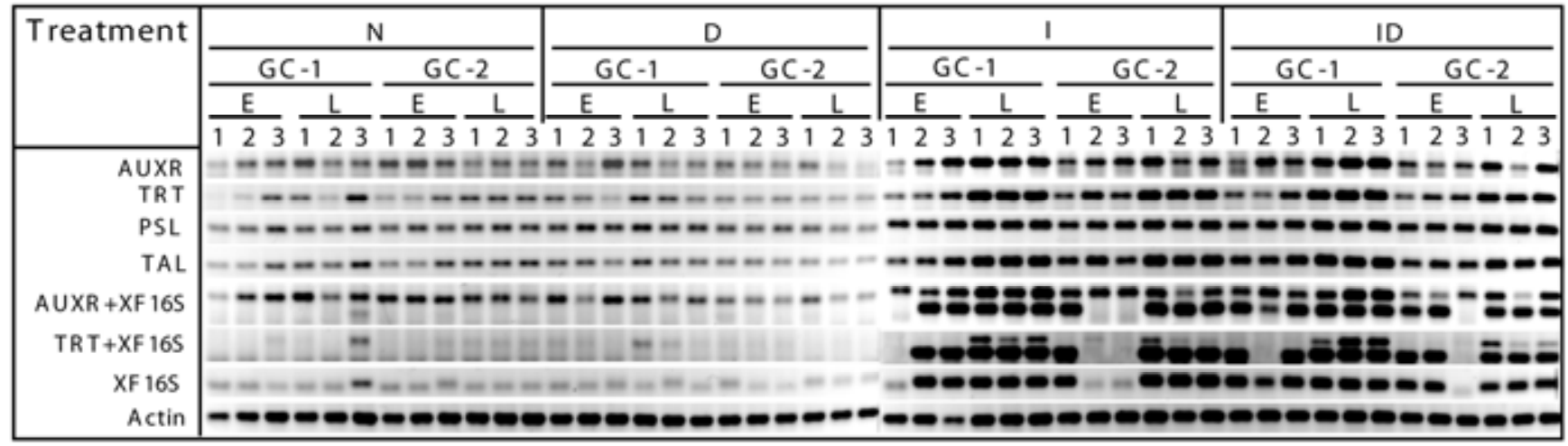

B
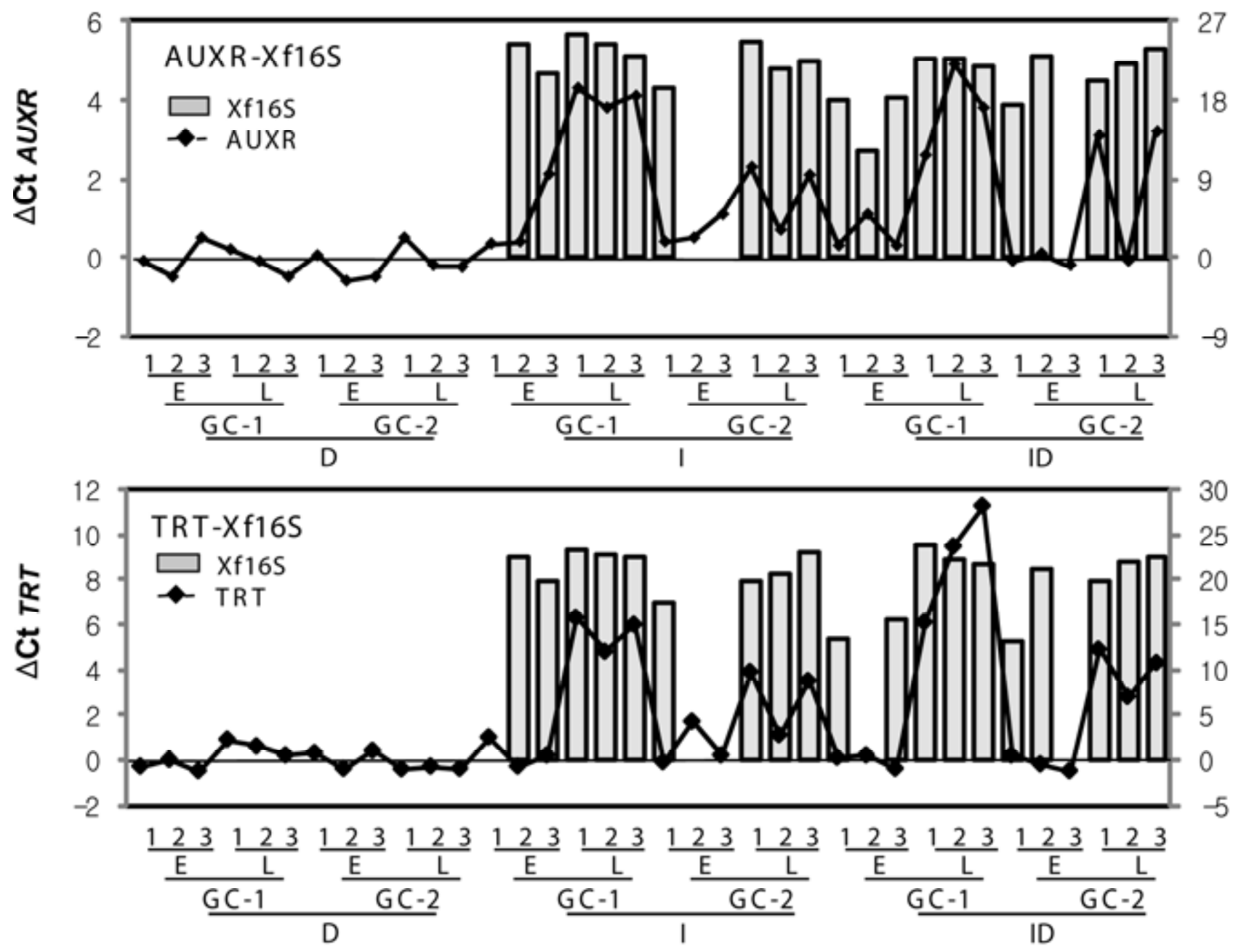

Fig. 6. Evaluation of the dual Pierce's disease (PD) diagnostic system as a practical tool to determine PD-infected status. A, Conventional polymerase chain reaction (PCR) analysis of marker genes. B, Real-time PCR analysis of multiplexed marker genes using combinations of TRT and AUXR with Xf16S. Difference of threshold cycles $(\Delta \mathrm{Ct})$ was calculated by subtracting average $\mathrm{Ct}$ of each gene from the average $\mathrm{Ct}$ of nontreated control. Individual treatments were noninoculated control, drought-stressed, Xylella fastidiosa-inoculated, and treated with X. fastidiosa-infection and drought. Abbreviations: E, early sample (4 weeks after treatment [WAT]); L, late sample (8 WAT); GC, growth chamber, which indicates two separately controlled growth chambers. Serial numbers on top lines denote three grapevine samples tested as a set under the same experimental conditions. 
of X. fastidiosa infection and not of drought stress. We note, however, that ongoing studies in our laboratory indicate a synergistic effect of drought stress on $X$. fastidiosa-induced gene expression, which is consistent with an interaction between PD development and water deficit. Such a result is not unexpected, because it supports several previous studies demonstrating that drought-stressed plants often develop more severe disease than well-watered individuals $(15,23,24)$.

Conclusion. The current work demonstrates the potential utility of host-derived biomarkers. We provide clear evidence of a host transcriptional pathway that is induced by $X$. fastidiosa infection, occurs prior to the onset of visual disease symptoms, is independent of water deficit, and, when used in conjunction with pathogen biomarkers, can yield potentially valuable complementary data. Nevertheless, the utility of these particular genes for routine diagnosis of $\mathrm{PD}$ will require testing under field conditions to establish their efficacy. Moreover, we suggest that it may be possible to identify host biomarkers that are superior to those studied here. Such biomarkers would be induced systemically, even in plants with patchy patterns of infection, and, thus, avoid the currently serious challenge of mis-sampling of asymptomatic plants. Whether such genes exist and, if so, whether their induction would be early and specific to $X$. fastidiosa infection are issues for further investigation.

\section{ACKNOWLEDGMENTS}

This work was supported by the research grant from the California Department of Food and Agriculture (contract number 02-0150: Genomic analysis of Xylella fastidiosa-grape interaction) and by the Dong-A University research fund.

\section{LITERATURE CITED}

1. Altschul, S. F., Madden, T. L., Schaffer, A. A., Zhang, J., Zhang, Z., Miller, W., and Lipman, D. J. 1997. Gapped BLAST and PSI-BLAST: a new generation of protein database search programs. Nucleic Acids Res. 25:3389-3402.

2. Banks, D., Albibi, R., Chen, J., Lamikana, O., Jarret, R. L., and Smith, B. J. 1999. Specific detection of Xylella fastidiosa Pierce's disease strains. Curr. Microbiol. 39:85-88.

3. Belgrader, P., Benett, W., Hadley, D., Long, G., Mariella, R., Milanovich, F., Nasarabadi, S., Nelson, W., Richards, J., and Stratton, P. 1998. Rapid pathogen detection using a microchip PCR array instrument. Clin. Chem. 44:2191-2194.

4. Belgrader, P., Smith, J. K., Weedn, V. W., and Northrup, M. A. 1998. Rapid PCR for identity testing using a battery-powered miniature thermal cycler. J. Forensic Sci. 43:315-319.

5. Bextine, B., Blua, M., Harshman, D., and Miller, T. A. 2005. A SYBR green-based real-time polymerase chain reaction protocol and novel DNA extraction technique to detect Xylella fastidiosa in Homalodisca coagulate. J. Econ. Entomol. 98:667-672.

6. Bohm, J., Hahn, A., Schubert, R., Bahnweg, G., Adler, N., Nechwatal, J., Oehlmann, R., and Osswald, W. 1999. Real-time quantitative PCR: DNA determination in isolated spores of the mycorrhiza fungus Glomus mosseae and monitoring of Phytophthora infestans and Phytophthora citricola in their respective host plants. J. Phytopathol. 147:409-416.

7. Chang, C. J., Garnier, M., Zreik, L., Rossetti, V., and Bove, J. M. 1993. Culture and serological detection of the xylem-limited bacterium causing citrus variegated chlorosis and its identification as a strain of Xylella fastidiosa. Curr. Microbiol. 27:137-142.

8. Davis, M. J., Purcell, A. H., and Thomson S. V. 1978. Pierce's disease of grapevines: isolation of the causal bacterium. Science 199:75-77.

9. De Souza, A. A., Takita, M. A., Coletta-Filho, H. D., Caldana, C., Goldman, G. H., Yanai, G. M., Muto, N. H., de Oliveira R. C., Nunes, L. R., and Machado, M. A. 2003. Analysis of gene expression in two growth states of Xylella fastidiosa and its relationship with pathogenicity. Mol. Plant-Microbe Interact. 16:867-875.

10. Eun, A. J. C., Seoh, M. L., and Wong, S. M. 2000. Simultaneous quantitation of two orchid viruses by the TaqMan real-time RT-PCR. J. Virol. Methods 87:151-160.

11. Fedorova, M., van de Mortel, J., Matsumoto, Pa A., Cho, J., Town, C. D., VandenBosch, K. A., Gantt, J. S., and Vance C. P. 2002. Genome-wide identification of nodule-specific transcripts in the model legume
Medicago truncatula. Plant Physiol. 130:519-537.

12. Goes da Silva, F., Iandolino, A., Al-Kayal, F., Bohlman, M. C., Cushman, M. A., Lim, H., Ergul, A., Figueroa, R., Kabuloglu, E. F., Osborne, C., Rowe, J., Tattersall, E., Leslie, A., Xu, J., Baek, J., Cramer, G. R., Cushman, J. C., and Cook, D. R. 2005. Characterizing the grape transcriptome; Analysis of expressed sequence tags from multiple Vitis species and development of a compendium of gene expression during berry development. Plant Physiol. 139:574-597.

13. Goodwin, P. H., Devay, J. E., and Meredith, C. P. 1988. Roles of water stress and phytotoxin in the development of Pierce's disease of the grapevine. Physiol. Mol. Plant Pathol. 32:1-16.

14. Hill, B. L., and Purcell, A. H. 1995. Multiplication and movement of Xylella fastidiosa within grapevine and four other plants. Phytopathology 85:1369-1372.

15. Hopkins, D. L. 1989. Xylella fastidiosa: xylem-limited bacterial pathogen of plants. Annu. Rev. Phytopathol. 27:271-290.

16. Hopkins, D. L. 2001. Xylella fastidiosa. Pages 201-213 in: Laboratory Guide for Identification of Plant Pathogenic Bacteria, 3rd ed. American Phytopathological Society, St. Paul, MN.

17. Iandolino, A. B., Goes da Silva, F., Lim, H., Choi, H., Williams, L. E., and Cook, D. R. 2004. High-quality RNA, cDNA and derived EST libraries from grapevine (Vitis vinifera L.). Plant Mol. Biol. Rep. 22:269-278.

18. Lee, R. F., Raju, B. C., Nyland, G., and Goheen, A. C. 1982. Phytotoxin(s) produced in culture by the Pierce's disease bacterium. Phytopathology 72:886-888

19. Liang, F., Holt, I., Pertea, G., Karamycheva, S., Salzberg, A. L., and Quackenbush, J. 2000. An optimized protocol for analysis of EST sequences. Nucleic Acids Res. 28:3657-3665.

20. Lin, H., Doddapaneni H., Takahashi Y., and Walker M. A. 2007. Comparative analysis of ESTs involved in grape responses to Xylella fastidiosa infection. BMC Plant Biol. doi:10.1186/1471-2229-7-8

21. Machado, M. A., Souza, A. A., Coletta-Filho, H. D., Kuramae, E. E., and Takita, M. A. 2001. Genome and pathogenicity of Xylella fastidiosa. Mol. Biol. Today 2:33-43.

22. MacNeil, J. S. 2004. Better biomarkers for the diagnostics labyrinth. Pages 24-33 in: Genome Technology. The Genome Web, New York.

23. McElrone, A. J., Sherald, J. L., and Forseth, I. N. 2001. Effects of water stress on symptomatology and growth of Parthenocissus quinquefolia infected by Xylella fastidiosa. Plant Dis. 85:1160-1164.

24. McElrone, A. J., Sherald, J. L., and Forseth, I. N. 2003. Interactive effects of water stress and xylem-limited bacterial infection on the water relations of a host vine. J. Exp. Bot. 54:419-430.

25. Minsavage, G. V., Thompson, C. M., Hopkins, D. L., Leite, R. M., and Stall, R. E. 1994. Development of polymerase chain reaction protocol for detection of Xylella fastidiosa in plant tissue. Phytopathology 84:456-461.

26. Monteiro, P. B., Renaudin, J., Jagoueix-Eveillard, S., Ayres, A. J., Garnier, M., and Bove, J. M. 2001. Catharanthus roseus, an experimental host plant for the citrus strain of Xylella fastidiosa. Plant Dis. 85:246-251.

27. Mumford, R. A., Boonham, N., Tomlinson, J., and Barker, I. 2006. Advances in molecular phytodiagnostics-new solution for old problem. Eur. J. Plant Pathol. 2006:1-19.

28. Mumford, R. A., Walsh, K., Barker, I., and Boonham, N. 2000. Detection of Potato mop top virus and Tobacco rattle virus using a multiplex realtime fluorescent reverse-transcription polymerase chain reaction assay. Phytopathology 90:448-453.

29. Nome, S. F., Raja, B. C., Goheen, A. C., Nyland, G., and Docampo, D. 1980. Enzyme-linked immunosorbent assay for Pierce's disease bacteria in plant tissues. Phytopathology 70:746-749.

30. Oliveira, A. C., Vallim, M. A., Semighini, C. P., Araujo, W. L., Goldman, G. H., and Machado, M. A. 2002. Quantification of Xylella fastidiosa from citrus trees by real-time polymerase chain reaction assay. Phytopathology 92:1048-1054.

31. Persson, K., Hamby, K., and Ugozzoli, L. A. 2005. Four-color multiplex reverse transcription polymerase chain reaction-overcoming its limitations. Anal. Biochem. 344:33-42.

32. Roberts, C. A., Dietzgen, R. G., Heelan, L. A., and Maclean, D. J. 2000. Real-time RT-PCR fluorescent detection of tomato spotted wilt virus. J. Virol. Methods 88:1-8.

33. Ruzin, S. E. 1999. Plant Microtechnique and Microscopy. Oxford University Press, Oxford, NY.

34. Schaad, N. W., Berthier-Schaad, Y., Sechler, A., and Knorr, D. 1999. Detection of Clavibacter michiganesis subsp. sepedonicus in potato tubers by BIO-PCR and an automated real-time fluorescence detection system. Plant Dis. 83:1095-1100.

35. Schaad, N. W., Opgenorth, D., and Gaush, P. 2002. Real-time polymerase reaction for one-hour on-site diagnosis of Pierce's disease of grape in early season asymptomatic vines. Techniques 92:721-728.

36. Schoen, C. D., Knorr, D., and Leone, G. 1996. Detection of potato leafroll virus in dormant potato tubers by immuno-capture and a fluorogenic $5^{\prime}$ nuclease RT-PCR assay. Phytopathology 86:993-999. 
37. Shi, X. Y., Dumenyo, C. K., Hernandez-Martinez, Azad, R. H., and Cooksey, D. A. 2009. Characterization of regulatory pathways in Xylella fastidiosa: genes and phenotypes controlled by gacA. Appl. Environ. Microbiol. 75:2275-228.

38. Thorne, E. T., Stevenson, J. F., Rost, T. L., Labavitch, J. M., and Matthews, M. A. 2006. Pierce's disease symptoms: comparison with symptoms of water deficit and the impact of water deficit. Am. J. Enol. Viticult. 57:1-11.
39. Weller, S. A., Elphinstone, J. G., Smith, N. C., Boonham, N., and Stead, D. E. 2000. Detection of Ralstonia solanacearum strains with a quantitative, multiplex, real-time fluorogenic PCR (TaqMan) assay. Appl. Environ. Microbiol. 66:2853-2858.

40. Zhang, A. W., Hartman, G. L., Curio-Penny, B., Pedersen, W. L., and Becker, K. B. 1999. Molecular detection of Diaporthe phaseolorum and Phomopsis longicolla from soybean seeds. Phytopathology 89: 796-804. 